\title{
"ENJOINING" RES JUDICATA: THE FEDERAL-STATE RELATIONSHIP AND CONCLUSIVENESS OF SETTLEMENTS IN STOCKHOLDERS' DERIVATIVE SUITS*
}

THE only remedy shareholders have for breach of fiduciary duty by the officers of a corporation is the stockholder's derivative suit. ${ }^{1}$ Subject to procedural limitations, ${ }^{2}$ any shareholder may initiate such a suit, but the cause of action belongs solely to the corporation ${ }^{3}$ and individual shareholders can sue only when the corporation itself refuses to do so. ${ }^{4}$ After a derivative action has been begun by one group of stockholders, other groups may not only intervene in the initial suit 5 but may also bring separate derivative actions based on the same facts in other courts. ${ }^{B}$ Final judgment in one suit operates as res

*Breswick v. Briggs, 135 F. Supp. 397 (S.D.N.Y. 1955), appeal dismissed without ofinion, Civil No. 23661, 2d Cir., Jan. 23, 1956.

1. Bayer v. Beran, 49 N.Y.S.2d 2, 4 (Sup. Ct. 1944) ; Berlack, Stockholders' Suits: $A$ Possible Substitute, 35 Micr. L. Rev. 597 (1937). Theoretically, shareholders also can vote to remove the directors from office, but this remedy has little practical utility. See Hornstein, The Future of Corporate Control, 63 Harv. L. Rev. 476 (1950) ; Pierce, Security for Expenses in Stockholder's Derivative Actions, in CurRent TrEnds In State LegrslaTHON 388, 390 (1952).

2. The plaintiff in such an action must be a stockholder in fact at the time the suit is brought. Barnett v. Ground, 304 Mo. 593, 605, 263 S.W. 836, 839 (1924); Isaacs v. Milwaukee Chair Co, 229 Wis. 184, 282 N.W. 1 (1938). Some jurisdictions require in addition a showing that plaintiff was a stockholder at the time of the alleged breach of duty. Sec, c.g., Fen. R. Civ. P. 23(b) ; N.Y. Gen. Corp. Law \$ 61. An additional limitation imposed in an increasing number of jurisdictions is a requirement that stockholderplaintiffs possessing less than a certain amount of the shares of the corporation must secure defendants against all expenses incurred in the successful defense of any cause of action pleaded. See, e.g., Cal. Corp. Cone \$ 834 (1955) ; N.J. Rev. Stat. \$ 14:3-15 (Supp. 1954); N.Y. Gln. Corp. Law $\$ 61 \mathrm{~b}$; Pa. Stat. Ann. tit. 12, § 1322 (Purdon 1954). These statutes are applicable as well to actions in federal courts when jurisdiction is based on diversity of citizenship. Cohen v. Beneficial Industrial Loan Corp., 337 U.S. 541 (1949).

3. Continental Securities Co. v. Belmont, 206 N.Y. 7, 15, 99 N.E. 138, 141 (1912); Ballantine, Corporations 333 (2d ed. 1946) (collecting cases). All sums recovered therefore inure to the corporation. 13 Fletcher, Cyclopedia Private Corporattons $\$ 6028$ (frerm. ed. 1943) ; Stevens, CoRporatrons 799 (2d ed. 1949). If a shareholder is successful he is entitled to reimbursement for all proper expenditures made in the prosecution of the suit, including counsel fees. Pergament v. Frazer, 132 F. Supp. 323 (E.D. Mich. 1954); Hornstein, The Cotnsel Fee in Stockholder's Derivative Sutits, 39 Colum. L. Rev. 784, 788 (1939).

4. Hawes v. Oakland, 104 U.S. 450, 462 (1881) ; Fed. R. Civ. P. 23(b) ; Ballantine, Corporatrons 345 (2d ed. 1946). See Pierce, supra note 1, at 388 for the rationale underlying this rule.

5. Leave to intervene is generally granted, but will be denied if the equities of the situation require. Southern Pac. Co. v. Bogert, 250 U.S. 483 (1919); White v. British Type Investors, Inc., 130 N.J. Eq. 157, 21 A.2d 681 (Ch. 1941) ; Dresdner v. Goldman Sachs Trading Corp., 240 App. Div. 242, 269 N.Y. Supp. 360 (2d Dep't 1934).

6. Dana v. Morgan, 232 Fed. 85 (2d Cir. 1916); Brinckerhoff v. Bostwick, 99 N.Y. 185, 194, 1 N.E. 663,668 (1885). Contra, Goodbody v. Delaney, 80 N.J. Eq. 417, 83 
judicata in all suits, however, and bars further litigation on the underlying causes of action. ${ }^{7}$ Thus, when a number of cases involving the same alleged wrongs are pending, defendants can attempt to litigate the basic issues in the suit which appears most favorable to them by employing dilatory tactics in the other actions.

Judicial approval of a stipulation of settlement also operates as res judicata in all other suits. ${ }^{8}$ A settlement can be presented for approval even though it is accepted by only one plaintiff-shareholder. ${ }^{9}$ Hearings on the propriety of the settlement must be held. ${ }^{10}$ Objecting shareholders can intervene and are entitled to produce evidence and witnesses and to cross-examine all witnesses who appear for the proponents of the settlement. ${ }^{11}$ Moreover, at least under

At1. 988 (Ch. 1912) (shareholders may intervene but may not bring separate plenary action). A derivative suit is in personam, and thus can be litigated whenever the requisite jurisdiction over parties and subject matter is present. 13 Fletcher, Cyclopedia Private Corporations $\$ \$ 5986-93$ (perm. ed. 1943). It is not uncommon to have a number of suits pending against the same parties involving the same alleged wrongs.

7. Ratner v. Paramount Pictures, Inc., 6 F.R.D. 618, 619 (S.D.N.Y. 1942) ; Dresdner v. Goldman Sachs Trading Corp., 240 App. Div. 242, 244, 269 N.Y. Supp. 360, 363 (2d Dep't 1934). This is true for two reasons: the suit is a "true class action," and judgment in such an action is binding on all members of the class. Stella v. Kaiser, 218 F.2d 64 (2d Cir. 1954) ; 3 Moore, Federal Practice 1 If 23.08, 23.11 (2d ed. 1948). Also, since the "cause of action" adjudicated in a derivative suit is that of the corporation, once it has had its day in court subsequent litigation by its representatives is barred. Dana $v$. Morgan, 219 Fed. 313, 316 (S.D.N.Y. 1914), aff'd, 232 Fed. 85 (2d Cir. 1916) ; Potter v. Walker, 276 N.Y. 15, 27, 11 N.E.2d 335, 337 (1937); McLaughlin, The MIystcry of the Representative Suit, 26 GEo. L.J. 878 (1938).

8. Stella v. Kaiser, 218 F.2d 64 (2d Cir. 1954); Dana v. Morgan, 232 Fed. 85 (2d Cir. 1916) ; Milvy v. Sperry Corp., 36 N.Y.S.2d S81 (Sup. Ct. 1939).

9. Naitove v. Morrow, N.Y.L.J., Nov. 2, 1940, p. 1386, col. 4, aff'd, 260 App. Div. 1017, 24 N.Y.S.2d 1003 (1st Dep't 1940), discussed in Wood, Survey AND Refort 70-72 (1944), and Hornstein, Problems of Procedure in Stockholder's Derivative Suits, 42 Colum. L. REv. 574, 590 (1942). If a new board of directors negotiates a settlement with the wrongdoers, the court will consider the settlement even though all litigating shareholders refuse to accept it. Denicke v. Anglo California Nat'l Bank, 45 F. Supp. 524 (N.D. Cal. 1942), aff'd, 141 F.2d 285 (9th Cir. 1944) ; Perrine v. Pennroad Corp., 28 Del. Ch. 343, 43 A.2d 721 (Ch. 1945) ; Bysheim v. Miranda, 44 N.Y.S.2d 15 (Sup. Ct. 1943).

10. FED. R. Crv. P. 23(c) ; Cohen v. Young, 127 F.2d 721 (6th Cir. 1942) (failure to hold full hearings on all salient facts constitutes abuse of trial court's discretion). Under New York law such procedure is not mandatory before a derivative action will be dismissed. Dresdner v. Goldman Sachs Trading Corp., 240 App. Div. 242, 269 N.Y. Supp. 360 (2d Dep't 1934). However, a judgment entered on discontinuance of a derivative suit without such hearing is not a judgment "on the merits" and hence is not effective as res judicata. Winkelman v. General Motors Corp., 44 F. Supp. 960, 1020 (S.D.N.Y. 1942). Therefore, the practice of hearings and court approval of settlements has developed independent of statute. See, e.g., Bysheim v. Miranda, 44 N.Y.S.2d 15 (Sup. Ct. 1943) ; Beeber v. Empire Power Corp., 31 N.Y.S.2d 914 (Sup. Ct. 1941) ; Hornstein, Problems of Prncedure in Stockholder's Derivative Suits, 42 ColvM. L. REv. 574, 586-90 (1942).

11. Letter from Robert J. Fitzsimmons, Esq., referee in $Z$ enn v. Ansalone, the New York court proceeding considering the Alleghany derivative action settlement, to the Yale Law Journal, Nov. 29, 1955, on file in Yale Law Library. See note 21 infra and accompanying text. 
New York and federal practice, notice of the compromise and time of hearing is given to all stockholders. ${ }^{12}$ The settlement will be approved, however, unless the court finds that in view of the "probabilities of victory or defeat," the settlement is "unfair or unreasonable to the corporation."13 Objecting shareholders may appeal judicial approval of the settlement, ${ }^{14}$ but absent fraud or collusion the final judgment is binding on the corporation and all its stockholders. ${ }^{15}$

To the conditions necessary to give conclusive effect to a settlement decree, the recent case of Breswick $v$. Briggs ${ }^{16}$ added the requirement that all actively litigating shareholders must participate in negatiation of the settlement. A number of derivative suits had been initiated against the directors of Alleghany Corporation. ${ }^{17}$ By June 1955, all actions except Breswick, and three other cases filed in federal court, ${ }^{18}$ had been consolidated under one general counsel.

12. In federal courts, notice is mandatory. FED. R. CIv. P. 23(c). In New York, notice was given in the first case holding that a stockholder's judgment based on settlement was effective as res judicata. Gerith Realty Co. v. Normandie Nat'l Securities Corp., 154 Misc. 615,276 N.Y. Supp. 655 (Sup. Ct. 1933), aff'd, 266 N.Y. 525 (1934). Subsequent litigants have followed this procedure, even though it has apparently never been held to be mandatory. Ballantine, Conforations 364 (2d ed. 1946) ; Hornstein, Problems of Procedure in Stockholder's Derivative Suits, 42 Colum. L. Rev. 574, 588 (1942). See also Perrine v. Pennroad Corp., 28 Del. Ch. 342, 43 A.2d 721 (Ch. 1945) (court practice is to require notice).

13. The complete formula is: "[T]he court must weigh the probabilities and possibilities of victory or defeat as indicated by the legal and factual situation presented. If uch considerations lead to the conclusion that the settlement ... is not unfair or unreasonable to the corporation ...., then the action of the plaintiffs in compromising the suit should be approved." Neuberger v. Barrett, N.Y. Sup. Ct., June 25, 1942 (unpublished apinion), quoted in Winkelman v. General Motors Corp., 48 F. Supp. 490, 493 (S.D.N.Y. 1942), and Bysheim v. Miranda, 44 N.Y.S.2d 15, 23 (Sup. Ct. 1943).

14. Cohen v. Young, 127 F.2d 721 (6th Cir. 1942); Posen v. Cowdin, 267 App. Div. 158, 44 N.Y.S.2d 842 (1st Dep't 1943); 3 MLone, Federal Practice $\uparrow$ 23.24(5) (2d ed. $1948)$.

15. Gerith Realty Co. v. Normandie Nat'l Securities Corp., 154 Misc. 615, 276 N.X. Supp. 655 (Sup. Ct. 1933), aff'd, 266 N.Y. 525 (1934); cases cited note 8, supra; McLaughlin, Capacity of Plaintiff-Stockholder to Terminate a Stockholder's Stit, 46 Y ALE L.J. 421,430 (1936).

16. 135 F. Supp. 397 (S.D.N.Y. 1955), appeal dismissed without opinton, Civil No. 23661, 2d Cir., Jan. 23, 1956.

17. The first of these actions was begun in April 1954. Memorandum for Defendants, p. 4, Breswick v. Briggs, 135 F. Supp. 397 (S.D.N.Y. 1955). As of February 1955, when the Bresaick action was filed, a total of eighteen suits had been brought in the New York and federal courts, Statement by Robert Young, N.Y. Times, May 5, 1955, p. 51, col. 6. All these cases primarily concern Alleghany's relinquishment of its control of the Chesapeake \& Ohio Railroad and its part in the election of the "Alleghany-YoungKirby" slate to the board of the New York Central Railroad. Memorandum for Defendants, p. 3, Breswick v. Briggs, supra.

18. Memorandum for Defendants, p. 3, Breswick v. Briggs, supra note 17. Still another derivative suit, Eisenberg v. Briggs, was begun in the district court for the Southern District of New York on August 9, 1955, and remains unconsolidated. Record, p. 72, Breswick v. Briggs, stpra. 
Defendants had moved in May to consolidate these remaining suits under the general counsel, but hearings on the motion were delayed until late August at the request of counsel for Breswick. ${ }^{19}$ Before that time, however, the defendant-directors had announced the negotiation of a settlement with the general counsel ${ }^{20}$ and the submission of the settlement to the New York Supreme Court for approval. ${ }^{21}$ In federal court the Breswick plaintiffs, claiming no knowledge of the negotiations and no opportunity to enter them, ${ }^{22}$ moved for an injunction staying state court consideration of the agreement on grounds of collusion. ${ }^{23}$

The federal district court found that although the allegations of collusion had not been established, ${ }^{24}$ the conduct of the defendants in negotiating the compromise without consulting the active Breswick plaintiffs was inequitable, and that the defendants should not be permitted to profit by it.25 The court

19. Record, p. 51, Breswick v. Briggs, supra note 18 .

20. N.Y. Times, Aug. 2,1955 , p. 31 , col. 6 . The terms of the settlement are: (1) payment by the defendants to Alleghany of $\$ 700,000$; (2) an agreement by certain defendants to protect the corporation from loss on its investment in 600,000 shares of New York Central Stock, and to ensure it a $4 \frac{1}{2} \%$ return on its investment; and (3) a similar guarantee for all other joint ventures in which the corporation participates with certain of the defendants. Id., p. 35 , col. 1 .

21. Breswick v. Briggs, 135 F. Supp. 397,403 (S.D.N.Y. 1955). The settlement was referred to a referee who held the initial hearing on the proposal in September 1955.

22. The defendants justified the exclusion of plaintiffs' counsel from settlement negotiations on the grounds that the Breswick action was only a step in the plaintiffs' battle for control of Alleghany, and alleged that plaintiffs would not be willing to compromise for any amount. Supplemental Brief for Defendants, p. 21, Breswick v. Briggs, supra note 21 .

23. The plaintiffs also moved for summary judgment on five of the seven counts alleged in their complaint. Defendants moved to consolidate this action with all others and to designate the general counsel as general counsel in these suits also. Breswick $v$. Briggs, 135 F. Supp. 397, 399 (S.D.N.Y. 1955). The collusion charge was based on the allegation that the lawyer for the defendant corporation was closely associated with the firm that represented the defendant directors. Id. at 403 . The motion for summary judgment was denied by the court, $i d$. at $400-03$, while consolidation was refused without prejudice to its renewal after settlement proceedings had terminated, id. at 406-07.

24. Id. at 403.

25. Ibid. The court referred to the dominant role of the plaintiffs in establishing one of the bases of liability common to all the suits. Plaintiffs had based their derivative action on the proposition that during the period in question Alleghany had been subject to the jurisdiction of the Securities and Exchange Commission and that the defendants had acted wrongfully in registering the corporation with the Interstate Commerce Commission rather than with the former tribunal. The federal court had refused to rule on this point within the derivative suit context. Breswick v. Briggs, $130 \mathrm{~F}$. Supp. 953 (S.D. N.Y. 1955). The plaintiffs then intervened in hearings before the ICC on the same point, and, after the ICC decided against their contention, appealed that decision. In Breswick v. United States, CCH FEd. SEC. L. Rep. I 90,737 (S.D.N.Y. Nov. 18, 1955), a threejudge district court held that Alleghany had been subject to the SEC and that a preferred stock issuance under ICC authority was null and void. However, the court ruled that the corporation had come under SEC control sometime between May 21, 1954 and "at the very latest," May 24, 1955, which period is subsequent to many of the transactions which were alleged to have violated the Investment Company Act. Ibid. 
further held that intervention by the plaintiffs in a new forum on the limited issue of the fairness of the settlement was not an adequate remedy. ${ }^{26}$ It conceded that a federal injunction staying proceedings in the state court would probably be prohibited by section 2283 of the Judicial Code. ${ }^{2 \pi}$ But the court held that section 2283 did not prevent federal courts from enjoining a defendant from fully utilizing a state court judgment where its enforcement would be inequitable. ${ }^{28}$ It therefore enjoined defendants from pleading as a defense in the federal court any state court judgment approving a settlement "not negotiated with plaintiffs or their counsel."29 On appeal, the Second Circuit refused to pass upon the injunction, dismissing defendants' appeal per curiam on the ground that the order was "interlocutory." 30

It is doubtful whether federal courts have the power to grant such relief. The purpose of section 2283 is to prevent federal courts from interfering with state court proceedings. In view of the restrictive interpretation currently given section 2283 by the Supreme Court, 31 the Breswick court could not have enjoined the state court proceedings. ${ }^{32}$ It is true that several cases held that the predecessor of 2283 did not bar federal injunctions against the enforcement of inequitable state court judgments. ${ }^{33}$ These cases reasoned that injunctive relief was permissible because the state court proceedings had terminated, and hence would not be interrupted by issuance of the injunction, ${ }^{34}$ or because the

26. Breswick v. Briggs, 135 F. Supp. 397, 405 (S.D.N.Y. 1955).

27. Id. at 405. Section 2283 provides: "A court of the United States may not grant an injunction to stay proceedings in a State court except as expressly authorized by Act of Congress, or where necessary in aid of its jurisdiction, or to protect or effectuate its judgments." 28 U.S.C. $\$ 2283$ (1952).

28. Breswick v. Briggs, 135 F. Supp. 397, 405 (S.D.N.Y. 1955).

29. Id. at 406. It has been held that this injunction "was intended to benefit the Breswick plaintiffs only" and was not issued "on behalf of all stockholders." Breswick v. Briggs, Civil No. 98-371, S.D.N.Y., Nov. 10, 1955 (as yet unreported).

30. Briggs v. Breswick, Civil No. 23661, 2d Cir., Jan. 23, 1956 (unreported).

31. Amalgamated Clothing Workers v. Richman Bros. Co., 348 U.S. 511, 518 (1954) : "The prohibition of $\$ 2283$ is but continuing evidence of confidence in the state courts, reinforced by a desire to avoid direct conflicts between state and federal courts." See Toucey v. New York Life Ins. Co., 314 U.S. 118 (1941); Hale v. Bimco Trading, Inc., 306 U.S. 375 (1939); Mloore, Commentary on the Judiclal Cone 395-415 (1949).

32. Feldman v. Penuroad Corp., 60 F. Supp. 716, 718 (D. Del. 1945), aff'd, 155 F.2d 773 (3d Cir. 1946) ; cf. Kline v. Burke Constr. Co., 260 U.S. 226 (1922) ; Essanay Film Co. v. Kane, 258 U.S. 358 (1922) ; H. J. Heinz Co. v. Owens, 189 F.2d 505 (9th Cir. 1951).

33. Wells Fargo and Co. v. Taylor, 254 U.S. 175 (1920) (evidence inadmissible in state court) ; Simon v. Southern Ry., 236 U.S. 115 (1915) (void judgment); Marshall v. Holmes, 141 U.S. 589 (1891) (fraud) ; Western Union Tel. Co. v. Tompa, 51 F.2d 1032 (2d Cir. 1931) (evidence inadmissible in state court) ; National Surety Co. v. State Bank, 120 Fed. 593 (8th Cir. 1903) (accident or mistake).

Section 2283 in 1948 replaced $\$ 265$ of the Judicial Code of 1911, which read: "The writ of injunction shall not be granted by any court of the United States to stay proceedings in any court of a State, except in cases where such injunction may be authorized by any law relating to proceedings in bankruptcy." Act of March 3, 1911, c. 231, § 265, 36 STAT. 1162. See $2 S$ U.S.C. $\$ 2283$ (1952).

34. Simon v. Southern Ry., stpra note 33; Western Union Tel. Co. v. Tompa, supra note 33; see Essanay Film Mfg. Co. v. Kane, 258 U.S. 358 (1922). 
injunction coerced the parties rather than the courts. ${ }^{35}$ But while the Supreme Court has never overruled these cases, it has rejected their reasoning ${ }^{30}$ and expressed doubt as to their validity. ${ }^{37} \mathrm{~A}$ persuasive argument has been made that neither 2283 nor the Supreme Court cases construing it forbid federal courts to enjoin enforcement of judgments after state court proceedings have terminated. ${ }^{38}$ Where state courts would entertain an equitable direct attack on a judgment, it is argued, federal courts should be able to do so as well, and 2283 should be interpreted accordingly. ${ }^{39}$ But even this argument is unavailing in the Breswick situation, since there the state court proceedings had not yet terminated. Certainly the injunction issued by the district court nullified defendants' efforts in the state court almost as effectively as would the injunction against state court proceedings which is literally proscribed by 2283 . A judgment based upon settlement has value to a defendant only to the extent that it is effective as res judicata. Where other plaintiffs remain to continue a derivative suit on identical grounds, as in Breswick, a judgment which is not effective against all plaintiffs is substantially worthless.

Even if 2283 were inapplicable, the substantive grounds for the district court's ruling are obscure. Thus it would seem that, since the court had jurisdiction only because of diversity of citizenship, it could grant relief only where authorized by the applicable state law. ${ }^{40}$ Under New York law, equitable relief

35. Wells Fargo and Co. v. Taylor, 254 U.S. 175 (1920) ; Marshall v. Holmes, 141 U.S. 589 (1891) ; National Surety Co. v. State Bank, 120 Fed. 593 (Sth Cir. 1903).

36. The first ground, note 34 supra and accompanying text, was rejected in Hill v. Martin, 296 U.S. 393, 403 (1935) : "It [the term "proceedings in any court of a State"] includes all steps taken or which may be taken in the state court or by its officers from the institution to the close of final process." The second reason, note 35 supra and accompanying text, was repudiated in Oklahoma Packing Co. v. Oklahoma Gas \& Elec. Co., 30? U.S. 4, 9 (1939): "That the injunction was a restraint of the parties and was not formally directed against the state court itself is immaterial." The reasoning of Oklahoma had been stated as early as 1849 , but had apparently been ignored during the period of judicial hostility to $\$ 265$. See Peck v. Jenness, 48 U.S. (7 How.) $* 612, * 624-25$ (1849).

37. Toucey v. New York Life Ins. Co., 314 U.S. 118, 136 (1941) (foundation of these cases is "very doubtful").

38. See Moore, Conmentary on the Judicial Code 395-415 (1949).

39. Id. at 414. There is serious doubt that the Supreme Court would adhere to this interpretation, in view of the restrictive construction of $\$ 2283$ set forth in Amalgamatcd Clothing Workers v. Richman Bros. Co., 348 U.S. 511 (1954).

"Equitable direct attack" refers here to an independent action in equity or motion in a subsequent action to obtain relief from an admittedly valid judgment, on the grounds that certain extrinsic factors render full enjoyment of its benefits by the holder contrary to recognized principles of equity. This form of attack is often characterized as "collateral attack." See Griffith v. Bank, 147 F.2d 899 (2d Cir. 1945). However, that term should be limited to proceedings in which a declaration is sought that the judgment itself is void, and which require no showing of greater equity in favor of the challenging party. See 7 Moore, Federal Practice $\int 60.41$ (2) (2d ed. 1955).

40. It seems clear that Erie R.R. v. Tompkins, 304 U.S. 64 (193S), requircs that the federal court base its decision to grant or withhold relief on the law of the stat: of judgment, where the court is exercising diversity jurisdiction and is sitting in that state, whether "equitable" or "legal" relief is demanded. See Angel v. Bullington, 330 U.S. 183 (1947); 
from a judgment is granted only where "virtual fraud" is established, and where the circumstances which make enforcement of the judgment inequitable could not have been urged as grounds for relief in the original action. ${ }^{41}$ But in Brcszick, the court specifically rejected plaintiff's charges of collusion, the only conduct alleged which could be subsumed under the heading of fraud. ${ }^{42}$ And even if failure to notify active plaintiffs of the settlement negotiations were considered to amount to fraud, this issue could have been raised at the settlement hearings. ${ }^{43}$ The court apparently was cognizant of the limitations on direct attack in equity imposed by New York law, but believed that its use of the injunction device brought into play some general federal equity power. The cases it cited in support of its ruling were, however, pre-Erie ${ }^{44}$ decisions based on "federal" principles of equity never adopted in New York.45

Perhaps the best argument against the applicability of section 2283 to the decision is suggested by the Second Circuit's laconic dismissal of the appeal as "interlocutory." Since all "injunctions" are appealable, whether "interlocutory" or not, ${ }^{46}$ the dismissal of the appeal apparently holds that the district court's order was not in reality an injunction..$^{47}$ Because the purported injunction had reference to a state court judgment which might never materialize, and thus was hypothetical, the circuit court may have construed the order as a mere announcement by the district court of its intention not to uphold a plea

Guaranty Trust Co. v. York, 326 U.S. 99 (1945) ; Ruhlin v. New York Life Ins. Co., 304 U.S. 202 (1938). In all other situations, the full faith and credit clause would compel the same result. 7 Moore, Federal Practice $\Uparrow 60.37$ (3) (2d ed. 1955).

41. 775 Seventh Ave. Corp. v. Carroll, 266 N.Y. 155, 194 N.E. 68 (1935) (virtual fraud must be shown); Fuhrmann v. Fanroth, 254 N.Y. 479, 173 N.E. 685 (1930) (must be shown in original action if known at that time) ; Harris v. Interstate Training Service, 140 N.Y.S.2d 8 (Sup. Ct. 1955) (same) ; Finestone v. Frostholm, 69 N.Y.S.2d 556 (N.Y. Munic. Ct. 1947) (rule applies to consent judgments as well).

42. See text at note 24 supra.

43. The Breszick decision was submitted to the New York Supreme Court in support of a motion to vacate the order referring the settlement to a referee on the ground that it had been negotiated in an inequitable manner. The motion was denied, and this decision was affirmed per curiam by the Appellate Division of the Supreme Court. The Appellate Division stated that the exclusion of these plaintiffs was improper only if it had an adverse iffect on the terms of the settlement, and this issue should properly be raised at the hearings on the settlement. Zenn v. Anzalone, 146 N.Y.S.2d 287 (1st Dept. 1955).

44. Erie R.R. v. Tompkins, 304 U.S. 64 (1938).

45. See note 41 supra and accompanying text.

46. 28 U.S.C. \& 1292 (1952).

47. The correctness of the Second Circuit's decision is at least dubious. See MOore, COM-

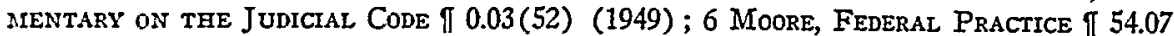
(2d ed. 1953). Had the plaintiff asked for an injunction of the type granted by the district court, an order denying the injunction but giving an "advisory opinion" to the same effect would have been grounds for an appeal within the clear mandate of 28 U.S.C. $\$ 1292$ (1952). Also, the circuit court did not order the injunction itself to be vacated and presumably it is still in effect. Theoretically, therefore, the defendants can be held in contempt of court if they amend their answer to include a judgment based on the settlement. However, this result can be avoided by asking leave of the court to amend. And denial of such permission by the court would probably be reversible error. 
of res judicata based on a state court judgment, if and when such a plea should be entered. And if the order was not an injunction for purposes of appeal, it could scarcely be an injunction forbidden by 2283 . However, while the suggested rationale avoids 2283 , it reinforces the conclusion that the decision was erroneous. The res judicata effect of a state court judgment is determined by the applicable state law. ${ }^{48}$ And the New York decisions establish clearly that a plea of res judicata cannot be denied on the grounds advanced in Brestuich.4 Indeed, the court's realization that it could not deny the plea probably dictated its adoption of the injunction device.

Wholly apart from considerations of procedure and choice of law, the added protection which the Breswick rule would give to litigating shareholders does not seem to justify its use. Breswick would deny res judicata effect to a settlement unless all litigating shareholders either had participated in the negotiations or had been consolidated under a general counsel. But settlement negotiations are often informal and sporadic, and the court did not attempt to determine the difficult questions of when notification must be given and what would constitute "participation." And since a settlement agreed to by any plaintiff-shareholder can be submitted to the court and approved over the objections even of a majority of the active litigants, ${ }^{50}$ the only possible advantage of participation is that a plaintiff displeased with the terms of the compromise can present his views to the negotiating parties before the agreement is submitted to the court. But if others choose to submit the settlement without his approval, and the court finds the compromise is "not unfair or unreasonable," it will still be approved. Moreover, identical considerations vitiate the effectiveness of the requirement that defendants consolidate all actions; the settlement need only be agreed to by one of the consolidated plaintiffs in order to be submitted to the court. ${ }^{51}$ Furthermore, since many state and federal courts may have concurrent jurisdiction, consolidation will often be difficult and in some cases impossible. ${ }^{52}$

48. National Lead Co. v. Nulsen, 131 F.2d 51, 56 (8th Cir. 1942); Illinois Cent. R.R. v. Moore, 112 F.2d 959, 966 (5th Cir. 1940); cases cited at note 40 supra.

49. See note 41 supra and accompanying text.

50. See note 9 supra.

51. The general counsel has no greater power or right to negotiate a settlement or to block the submission of any settlement to the court for approval than does the attorney for any other shareholder. Typically, the general counsel has powers to issue and receive all papers, to initiate and conduct all pretrial examinations, and to have charge of the conduct of the trial. See Order of Consolidation, Zenn v. Anzalone, Civil No. 92-205, S.D.N.Y., May 18, 1954, pp. 4-5 (unreported order) (page citations are from typewritten copy on file in Yale Law Library), stating explicitly that consolidation is ordered "without prejudice" to any rights which any plaintiff might have if there were no consolidation. See also Greenberg v. Giannini, 50 F. Supp. 33, 34 (S.D.N.Y. 1943), aff'd, 140 F.2d 550 (2d Cir. 1944); 5 Moore, Federal Practice ff 42.02 (2d ed. 1951).

52. See note 6 supra and accompanying text. Two courts, with similar actions before them, might each refuse to order consolidation unless the action were to be decided in its own forum. If this occurred, there could be no binding determination of venue unless both were in the same judicial hierarchy. Under present law, both cases would proceed until 
To disapprove Breswick is not to say that results reached in the absence of the new rule it creates are completely satisfactory. Plainly, existing settlement procedure does not fully protect the interests of all stockholder-plaintiffs. Shareholders litigating elsewhere are forced to abandon their own suits temporarily and transfer their attention to a new case and forum if they are displeased with the compromise. In the hearings the important procedural weapons of pretrial examination and subpoenaing of corporate records are not available. ${ }^{33}$ And since "probability of victory or defeat" is an extremely speculative standard,"3: only those settlements blatantly advantageous to defendants fail to meet the judicial test of fairness. ${ }^{55}$ To upset a compromise, objectors must show either that the settlement was tainted by fraud or collusion or that the terms of the agreement were unduly generous. ${ }^{\text {jo }}$ Proving fraud or collusion is notoriously difficult, and absent such proof the burden the objector carries is "probably unsustainable." "st

Despite these inequities, it is unlikely that many jurisdictions will make settlement of derivative actions substantially more difficult than it now is. Compromise of litigation is generally encouraged in order to reduce administrative burden and expense to courts and litigants. ${ }^{58}$ It is true that a plaintiff who compromises a derivative suit terminates the rights of others as well as his own ; and for this reason many jurisdictions require court approval of settle-

one was adjudicated, whereupon the other suit would be foreclosed. See note 7 supra and accompanying text. If the burden of consolidation were shifted, the defendants might be forced to litigate the same matters twice whenever this problem arose. Such an occurrence would undoubtedly be rare, but when it happened the resulting impasse would be complete.

53. Pretrial examination is denied because the issues to be determined in the hearings are deencd to be too limited. In some hearings objecting stockholders have been permitted t' ste any records of the corporation which have been examined by counsel for other stockholder plaintiffs during the litigation, but these appear to be the only records to which they have access. Letter from Robert J. Fitzsimmons, Esq., referee in Zenn v. Anzalone, to the Yale Law Journal, Nov. 29, 1955, on file in Yale Law Library. See also Hornstein, The Future of Corporate Control, 63 HARv. L. Rev. 476, 480 (1950): "In stockholder litigation where corporate records and other evidence needed to prove improper conduct are often within the control of the defendants, preliminary examination is particularly essential."

54. See note 13 supra.

55. Between 1932 and 1942, in New York state and federal courts, thirty-six settlements were offered for court approval. Of these, only two were not approved. One of these actions was subsequently litigated and resulted in a judgment for defendants. In the other, a larger settlement resulted. WOOD, SURVEY AND REPORT 42, 93 (1944). The approved settlements averaged $3 \%$ of the amount demanded in the complaint. Id. at 7; Hornstein, Legal Contrals for Intra-Corporate Abuse, 41 ColuM. L. Rev. 405, 426 (1941).

56. Fielding v. Allen, 99 F. Supp. 137 (S.D.N.Y. 1951); Bysheim v. Miranda, 44 N.Y.S.2d 15 (Sup. Ct. 1943).

57. Fielding v. Allen, supra note 56, at 141 .

58. Masterson v. Pergament, 203 F.2d 315, 330 (6th Cir. 1953) ; Hornstein, New Aspects of Stockholders' Derivative Suits, 47 Colum. L. Rev. 1, 19 (1947) ; Keefe, Levy i Donavan, Lee Defeats Ben Hur, 33 ConNell L.Q. 327, 343 (1948); McLaughlin, Capacity of Plaintiff-Shareholder to Terminate a Stockholder's Suit, 46 YALE L.J. 421, 426 (1936); Note, 54 Harv. L. Rev. $\$ 33$ (1941). 
ments. ${ }^{59}$ But it is also true that plaintiffs seldom have more than a trivial financial interest in the recovery they seek on behalf of the corporation, ${ }^{\circ 1}$ so that extreme solicitude for the interests of nonassenting plaintiffs is seldom warranted. Moreover, these suits are extremely burdensome to parties defendant, and have often been the subject of abuse. ${ }^{61}$ These considerations have led courts to establish existing low standards for approval of settlements.

No pat formula is likely to solve the problems posed by settlement of derivative suits. It would seem, however, that courts are not properly implementing the aims of the rule requiring judicial supervision of settlements when theyr grant approval, over protest from active litigants, merely because a "reasonable man" could have negotiated such an agreement. For the purpose of the rule is not only to prevent fraud or collusion, but to ensure that compromise will take place only where it serves the best interests of the corporation." Improvement may lie in the direction of a more restrictive standard which will require trial courts to take a more active role in safeguarding the interests of nonassenting shareholders. But whatever the merits of a stricter standard, the advisability of its adoption is a matter for each jurisdiction to determine for itself. Dissatisfaction with existing procedure should not find expression through the device of enjoining parties from enjoying the benefits of judgments validly obtained in other jurisdictions.

59. See, e.g., note 10 supra. See also Colo. R. CIv. P. 23 (c) ; N.J. R. Crv. P. 4:36-3; PA. R. Civ. P. 2230(b) ; Tex. R. Crv. P. 42(c); Whitten v. Dabney, 171 Cal. 621, 154 Pac. 312 (1915).

60. See, e.g., Wood, op. cit. supra note 47, at 112, app. D.

61. See Berlack, Stockholders' Suits: A Possible Substitute, 35 Mick. L. Rev. 597, 604-05; Pierce, Security for Expenses in Stockholder's Derivative Actions, in Current Trends in State Legrslation 38S, 394-95 (1952); Pound, Visitatorial Jutrisdiction aner Corporations in Equity, 49 HARv. L. Rev. 369, 395 (1936).

62. Cohen v. Young, 127 F.2d 727 (6th Cir, 1942); Berger v. Dyson, 111 F. Supp. 533 (D.R.I. 1953); Pergament v. Frazer, 93 F. Supp. 13 (E.D. Mich. 1950). 